\title{
Anaokulu Öğretmenlerine Verilen Çocukta Yabancı Cisim Aspirasyonlarına Yaklaşım Eğitimlerinin Değerlendirilmesi
}

The Evaluation of Approach Training on Foreign Body Aspirations in Children Given to Kindergarten Teachers Aslı KURTGÖZ ${ }^{1}$, Zehra İNCEDAL SONKAYA ${ }^{2}$

\section{ÖZ}

$\mathrm{Bu}$ çalışma anaokulu öğretmenlerine verilen çocukta yabancı cisim aspirasyonlarına yaklaşım eğitimlerinin etkinliğini değerlendirmek amacıyla yapılmıştır. Araştırma 14.09.2020-15.01.2021 tarihleri arasında kesitsel tipte çalışma olarak yürütülmüştür. Araştırma, Amasya il merkezinde bulunan tüm resmî anaokullarında görev yapan 60 anaokulu öğretmeninden çalışmaya katılmayı kabul eden 48 öğretmenin katılımıyla gerçekleştirilmiştir. Çalışma kapsamında öğretmenlere eğitim maketi eşliğinde online olarak "çocukta havayolu tıkanıklığında ilkyardım yaklaşımı” konulu eğitim verilmiştir. Çalışmanın eğitim öncesi verileri araştırmacılar tarafından hazırlanan "kişisel veri toplama formu" ile "havayolu tıkanıklığına ilkyardım yaklaşımı bilgi düzeyi formu" (ön test) kullanılarak toplanmıştır. Eğitimden 4 hafta sonra bilgi düzeyi formu (son test) katılımcılara tekrar uygulanmıştır. Çalışmada katılımcıların havayolu tıkanıklığına ilk yardım yaklaşımı bilgi düzeyi formundan aldıkları ön test puan ortalamalarının $1,91 \pm 0,21$; son test puan ortalamalarının ise $7,12 \pm 0,28$ olduğu; bu puan farkın ileri düzeyde anlamlı olduğu belirlenmiştir ( $\mathrm{p}<0,001$, $\mathrm{Z}=-5,986)$. Bu çalışmada anaokulu öğretmenlerine çocukta yabancı cisim aspirasyonlarına yönelik verilen ilk yardım eğitiminin katılımcıların bilgi düzeyini artırmada etkili olduğu saptanmıştır.

Anahtar Kelimeler: Aspirasyon, Çocuk, Eğitim, Okul Öğretmenleri, Yabancı Cisimler.

\begin{abstract}
This study was carried out to evaluate the effectiveness of the training on the approach to foreign body aspiration in children given to kindergarten teachers. The research was conducted between 14.09.2020 and 15.01.2021 as a cross-sectional study. The research was carried out with the participation of 48 teachers who agreed to participate in the study who included 60 kindergarten teachers working in all public kindergartens in the city center of Amasya. Within the scope of the study, teachers were given online training on the "first-aid approach to airway obstruction in children" accompanied by a training model. The pre-training data of the study were collected using the "personal data collection form" and "first-aid approach in airway obstruction knowledge level form" (pre-test) prepared by the researchers. 4 weeks after the training, the questionnaire form (posttest) was applied to the participants again. In the study, the pre-test mean score of the participants from the first-aid approach to airway obstruction knowledge form was $1.91 \pm 0.21$; the post-test mean score was $7.12 \pm 0.28$; this score difference was determined to be highly significant ( $p<0.001, \mathrm{Z}=-5.986)$. In this study, it was determined that the first-aid training given to kindergarten teachers for foreign body aspiration in children was effective in increasing the knowledge level of the participants.
\end{abstract}

Keywords: Aspiration, Child, Training, School Teachers, Foreign Bodies.

\footnotetext{
Calısma için bir üniversitenin klinik arastırmalar etik kurulundan izin alınmıstır (Sayl: B.30.2.ODM.0.20.08/511). Bu calısma Amasya Üniversitesi Bilimsel Araştırma Projeleri Koordinasyon Birimi tarafindan desteklenmiştir (Proje Numarası: FMB-BAP 20-0442). Bu araștırma 12-13 Şubat 2021 tarihleri arasında Karadeniz Teknik Üniversitesi tarafindan düzenlenen Halk Sağlı̆̆ ve Hemșirelik Bilişimi Sempozyumu'nda sözel bildiri olarak sunulmuştur.

${ }^{1}$ Dr. Öğr. Üyesi, Aslı KURTGÖZ, Hemşirelik Esasları, Amasya Üniversitesi Terapi ve Rehabilitasyon Bölümü, asli.aydogan@amasya.edu.tr, ORCID: 0000-0001-5903-9389

${ }^{2}$ Dr. Öğr. Üyesi, Zehra İNCEDAL SONKAYA, Halk Sağlığı, Amasya Üniversitesi Sağlık Bakım Hizmetleri Bölümü, zehra.incedal@ amasya.edu.tr, ORCID: 0000-0002-5446-9707 


\section{GİRIŞ}

Yabanc1 cisim aspirasyonu (YCA), havayolunda kısmî ya da tam tıkanıklık meydana getiren bir durumdur. Tam tıkanma durumu, mekanik boğulma nedeniyle ventilasyonu ve oksijenizasyonu bozarak ölümle sonuçlanabilmektedir. Ölümün ana nedeni hipoksik-iskemik beyin hasarı ve daha az siklıkla pulmoner kanamadan kaynaklanmaktadır. ${ }^{1,2}$

YCA, laringeal kapanma refleksindeki yetmezlik, yetersiz yutma refleksi, ağız içine nesne alma alışkanlığı, riskli objenin ulaşılabilirliği, ihmal, eğitimsiz ebeveynler ve bakıcılar gibi gelişimsel, anatomik ve diğer nedenlerden dolayı küçük çocuklarda s1k olarak görülmektedir. ${ }^{2,3} \mathrm{Bu}$ nedenle YCA özellikle 5 yaşından küçük çocukluklarda kazara meydana gelen ani beklenmedik ölümlerin dördüncü sirasında yer

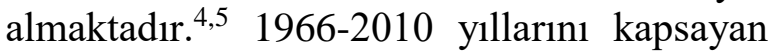
retrospektif bir çalışmada boğulma vakalarının \%94'ünün nesne-yiyecek aspirasyonu kaynaklı olduğu, vakaların \%95'inin ise 5 yaşından küçük çocuklar olduğu bildirilmiştir. ${ }^{6}$ Çocuklarda yabancı cisim aspirasyonu insidans 100.000 'de 0,66 ; YCA'ya bağlı ölüm oranı ise \%5-7 olarak bildirilmektedir. ${ }^{5,7}$ YCA acil müdahale gerektiren bir durumdur. ${ }^{8} \mathrm{Bu}$ bağlamda çocuklarda YCA durumunda acil yaklaşımın bilinmesi ölüm oranlarının azaltılması açısından önem arz etmektedir. Literatürde yabancı cisim aspirasyonuna bağlı son otuz yılda gözlenen ölüm oranlarındaki azalmanın halk eğitimi ile ilişkili olduğu bildirilmektedir. ${ }^{9}$

Çocuklarda en sık aspire edilen öğeler arasında kuruyemiş, patlamış mısır, madeni para, oyuncak, boya kalemleri, balon, toplu iğne gibi materyaller yer almaktadır. ${ }^{2,9,10}$ Cezayir'de 1989-2012 yıllarını kapsayan retrospektif bir çalışmada 2624 çalışma incelenmiş ve aspire edilen cisimlerin $\% 66,7$ 'sinin organik (yer fıstığı, ayçiçeği çekirdeği, fasülye ve buğday) olduğu belirlenmiştir. ${ }^{11}$ Aspire edilen cismin türü çocukluk dönemine göre de farklilık gösterebilmektedir. Okul çağındaki çocuklarda kalem uçları ve silgi; okul öncesi çocuklarda ise kuru yemiş, küçük oyuncak parçaları gibi objeler daha sık aspire edilmektedir. $^{1}$

10 Temmuz 2019 tarihli 30827 sayılı Resmî Gazetede ilan edilen Millî Eğitim Bakanlığ 1 Okul Öncesi Eğitim ve İlköğretim Kurumları Yönetmeliğinde Değişiklik Yapılmasına Dair Yönetmelikte, anaokulu kavramı "Eylül ayı sonu itibarıyla 36-68 aylık çocukların eğitimi amacıyla açılan okul" olarak tanımlanmıştır. ${ }^{12} \mathrm{Bu}$ doğrultuda anaokulu öğrencileri yaş aralığı itibariyle yabancı cisim aspirasyonları yönünden risk grubunu oluşturmaktadır.

Amerikan Pediatri Akademisi (AAP), 1-8 yaş aralığındaki çocuklarda havayoluna kaçan ve tam tıkanıklık oluşturan yabancı cismin çıkarılması için acil yaklaşımda Heimlich Manevrası uygulanmasinı önermektedir. $\mathrm{Bu}$ durumda yabancı cisim dışarı çıkarılıncaya kadar veya çocuk bilinçsiz/tepkisiz hale gelene kadar Heimlich Manevrası yapılması gerekmektedir. Çocuk bilinçsiz/tepkisiz hale geldiğinde ise derhal kardiopulmoner resüsitasyona (temel veya ileri yaşam desteği) başlanması önerilmektedir. ${ }^{13}$ Temel yaşam desteği (TYD) kalbi veya solunumu durmuş bireye kalp masajı ve yapay solunum ile yeterli doku perfüzyonu ve oksijenasyonu sağlamak için yapılan ilaçsız ve tıbbi ekipmansız işlemlerdir. ${ }^{14}$

Çocuklarda yabancı cisim aspirasyonu durumunda yapılacak ilk yardım uygulamaları konusunda ebeveynlerin ve diğer bireylerin (öğretmenler, akrabalar, bakıcılar vs.) bilinçlendirilmesi ve eğitilmesi önemli bir husustur. ${ }^{4,15}$ Çocukların günün büyük bir bölümünü okulda geçirmeleri, her okulda revir ve sağlık çalışanı bulunmaması durumları göz önüne alındığında öğretmenlerin YCA'ya ilk yardım yaklaşımını konusunda mutlaka yeterli bilgi ve beceriye sahip olması gerekmektedir. ${ }^{16}$ Nayir ve arkadaşları (2011) tarafından yapılan bir çalışmada öğretmenlerin $\% 86$ 'sının ilk yardım bilgisi düzeylerini yeterli bulmadıkları ve \%81'inin ilk yardım 
eğitimi almak istedikleri belirlenmiştir. ${ }^{17} \mathrm{Bir}$ başka çalışmada okul öncesi öğretmenlerinin ilk yardım bilgilerinin yeterli olmadığ bildirilmiştir. ${ }^{18}$ Dinçer ve arkadaşlarının (2000) çalışmasında ise okul öncesi eğitimcilerin \%62,3'ünün ilk yardım eğitimi almadığı; \%68,8'inin eğitim verdikleri çocuklarla ilgili ilk yardım gerektirecek bir durumla karşılaştıklarını ifade ettiği bildirilmiştir. ${ }^{19}$ Okul öncesi öğretmenleri yetiştiren kurumlarda örgün eğitim esnasında ve öğretmenlerin hizmet içi eğitimlerinde temel ilk yardım uygulamalarına ilişkin konulara çok fazla yer verilmemektedir. $\mathrm{Bu}$ nedenle öğretmenlere hizmet içi eğitimlerle temel ilk yardım konularına yaklaşım konusunda eğitimlerin verilmesi gerekliliği ön plana çıkmaktadır. $\mathrm{Bu}$ doğrultuda planlanan bu çalışmanın amacı Amasya il merkezindeki resmî anaokullarında görev yapan öğretmenlere verilen çocukta yabancı cisim aspirasyonlarına yaklaşım eğitimlerinin etkinliğini değerlendirmektir.

\section{MATERYAL VE METOT}

\section{Araştırmanın Türü}

Çalışma kesitsel tipte bir araştırmadır.

\section{Evren ve Örneklem}

Çalışmanın evrenini Amasya il merkezinde bulunan tüm resmî anaokullarında okul öncesi öğretmeni olarak görev yapan toplam 60 öğretmen oluşturmuştur. Araştırmada örneklem seçim yöntemine gidilmeyip evrenin tamamina ulaşılması hedeflenmiştir. $\mathrm{Bu}$ doğrultuda araştırmaya katılmayı kabul eden 48 öğretmenin gönüllü katılımıyla çalışma gerçekleştirilmiştir.

\section{Veri Toplama Araçları}

Araştırmanın verileri "kişisel veri toplama formu" ve "havayolu tıkanıklığına ilk yardım yaklaşımı bilgi düzeyi formu" kullanılarak toplanmıştır.

\section{Kişisel Veri Toplama Formu}

Katılımciların sosyodemografik özellikleriyle ilkyardım ve havayolu tıkanıklığına yönelik birtakım tanımlayıcı bilgilerini belirlemek amacıyla araştırmacılar tarafından hazırlanan form; yaş, medeni durum, meslekte çalışma y1lı, meslek hayatında ilkyardım uygulaması gerektirecek bir durumla karşılaşma vb. sorular içermektedir.

\section{Havayolu Tıkanıklığına İlk Yardım Yaklaşımı Bilgi Düzeyi Formu}

Katılımcıların, çocukta yabancı cisim aspirasyonlarına yaklaşım hakkındaki bilgi düzeylerini belirlemek amacıyla araştırmacılar tarafindan literatür doğrultusunda hazırlanan formda; havayolu açıklığını sağlama yöntemleri, havayolu tıkanıklığı türleri, havayolu tıkanıklığı belirtileri, havayolu tıkanıklığına ilk yardım yaklaşımı, çocuklarda temel yaşam desteği uygulama standartları vb. hakkında 10 soru yer almaktadır. ${ }^{13,20}$ Havayolu tıkanıklığına ilk yardım yaklaşımı bilgi düzeyi formunda yer alan sorulara katılımcilar tarafindan verilen doğru cevaplar " 1 "; yanlış cevaplar ise " 0 " olarak puanlandırılmıştır. $\mathrm{Bu}$ doğrultuda formdan alınabilecek en düşük puan 0 ; en yüksek puan ise 10 olarak belirlenmiştir.

\section{Verilerin Toplanması}

Araștırma 14.09.2020-15.01.2021 tarihleri arasında yürütülmüştür. Veriler pandemi süreci nedeniyle online formlar kullanılarak toplanmıştır. Bunun için veri toplama araçları internet ortamında yanitlanabilecek bir form haline getirilmiştir. Formun ilk bölümünde katılımcılara çalışmanın amacı ve süreci hakkında bilgilendirme sağlayan bir bilgilendirilmiş onam bölümü yer almıştır. Veri toplama araçlarına ilişkin bir bağlantı adresi elde edilerek, bu link öğretmenlere mesaj yolu ile ulaştırılmıştır. Araştırmacılar tarafindan ön test amaciyla katılımcilara anket linki gönderilmiştir. Ön test formlarını dolduran öğretmenlere çocukta havayolu tıkanıklığında ilk yardım yaklaşımı hakkında eğitim verilebilmesi için Amasya İl Milli Eğitim Müdürlüğü iş birliğinde bir video konferans programı üzerinden toplantı planlanmıştır. Öğretmenlerine eğitimin gün ve saati hakkında bilgilendirme mesaj1 
gönderilmiştir. Eğitim tarihinde ilgili video konferans programı üzerinden öğretmenlere çocuk maketi kullanılarak eğitim verilmiştir. Eğitim içeriğinde; çocuğun değerlendirilmesi (bilinç, havayolu, solunum, dolaşım), havayolu tıkanıklığı türleri, tıkanıklık belirtileri, tıkanık durumunda yapılması gereken ilk yardım uygulamaları ve tıkanıklığa bağlı olarak çocukta bilinç kapanmas1 durumunda yapilmas1 gereken uygulama (temel yaşam desteği) konularına yer verilmiştir. Eğitimi takiben 4 hafta sonra eğitimin etkinliğini değerlendirmek için katılımcılara "havayolu tıkanıklığına ilk yardım yaklaşımı bilgi düzeyi formu" linki son test amaciyla tekrar gönderilmiştir. Katılımcılardan online oluşturulan veri toplama formlarına ön ve son test puanlarını karşılaştırabilmek adına rumuz yazmaları istenmiştir. Ön test formunu tamamlayan 48 öğretmenin tamamı eğitime katılmış ve son test formlarını tamamlamıştır.

\section{Verilerin Değerlendirilmesi}

Araştırmadan elde edilen veriler, IBM SPSS V20 paket programı ortamında değerlendirilmiştir. Verilerin analizinde Bağımsız Örneklem t testi, Kruskall Wallis testi, Mann Whitney U testi ve Wilcoxon İşaretli Sıra testi kullanılmıştır. Analiz sonuçları ortalama \pm standart sapma ve frekans (yüzde) olarak ifade edilmiştir.
Araştırmada anlamlılık düzeyi $\mathrm{p}<0,05$ olarak alınmıştır.

\section{Araştırmanın Etik Yönü}

Çalışmaya başlamadan önce bir üniversitenin klinik araştırmalar etik kurulundan etik kurul izni (Say1: B.30.2.ODM.0.20.08/511) ve araştırmanın ilgili anaokullarında yürütülebilmesi için Amasya İl Milli Eğitim Müdürlüğü'nden çalışma izni (Sayı: 47613789-44E.11333344) alınmıştır. Bununla birlikte veri toplama araçları uygulanmadan önce katılımcıların bilgilendirilmiş gönüllü onamları alınmıştır.

\section{Destekleyen Kuruluş}

$\mathrm{Bu}$ çalışma Amasya Üniversitesi Bilimsel Araştırma Projeleri Koordinasyon Birimi tarafından desteklenmiştir (Proje Numarası: FMB-BAP 20-0442).

\section{Araştırmanın Sınırlılıkları}

$\mathrm{Bu}$ araştırma Amasya il merkezindeki resmi anaokullarında görev yapan öğretmenleri kapsamaktadır. Bu doğrultuda çalışmadan elde edilen veriler tüm okul öncesi öğretmenlerine ve diğer branşlardaki ögretmenlere genellenemez. Öğretmenlere verilen eğitimin pandemi nedeniyle yüz yüze ve birebir uygulamalı olmaması bir çalışmanın önemli bir kısıtlılığıdır.

\section{BULGULAR VE TARTIŞMA}

Tablo 1.Katılımcıların Sosyodemografik Özellikleri

\begin{tabular}{|c|c|c|}
\hline Özellikler & Sayı & $\%$ \\
\hline \multicolumn{3}{|l|}{ Yaş grubu } \\
\hline $25-34$ & 16 & 33,3 \\
\hline $35-44$ & 30 & 62,5 \\
\hline 45 ve üzeri & 2 & 4,2 \\
\hline Yaş Ortalaması (Ort. \pm SS) & \multicolumn{2}{|c|}{$36,60 \pm 4,6$} \\
\hline \multicolumn{3}{|l|}{ Cinsiyet } \\
\hline Kadin & 46 & 95,8 \\
\hline Erkek & 2 & 4,2 \\
\hline \multicolumn{3}{|l|}{ Medeni durumu } \\
\hline Evli & 45 & 93,8 \\
\hline Bekar & 3 & 6,3 \\
\hline \multicolumn{3}{|l|}{ Meslekte çalıșma süresi } \\
\hline $1-5$ y1l & 3 & 6,3 \\
\hline $6-10$ y1l & 11 & 22,9 \\
\hline 11 y1l ve üzeri & 34 & 70,8 \\
\hline Toplam & 48 & 100 \\
\hline
\end{tabular}

Anaokulu öğretmenlerinin sosyodemografik özellikleri Tablo 1'de sunulmuştur. Katılımcıların yaş ortalamasının $36,60 \pm 4,6$ olduğu, $\% 62,5^{\prime}$ 'inin 35-44 yaş grubunda yer aldı̆ $1, \% 95,8^{\prime}$ inin kadın, \%93,8'inin evli, \%70,8'inin ise meslekte çalışma süresinin 11 y1l ve üzeri olduğu belirlenmiştir (Tablo 1).

Anaokulu öğretmenlerinin ilkyardım ve havayolu tıkanıklığına yönelik tanımlayıcı özellikleri Tablo 2'de verilmiştir. 
Tablo 2. Katılımcıların İlkyardım ve Havayolu Tıkanıklığına Yönelik Tanımlayıcı Özellikleri

\begin{tabular}{|c|c|c|}
\hline Özellikler & Sayı & $\%$ \\
\hline \multicolumn{3}{|l|}{$\begin{array}{l}\text { Meslek hayatında ilkyardım } \\
\text { uygulaması gerektirecek bir durumla } \\
\text { karşılaşma durumu }\end{array}$} \\
\hline Evet & 30 & 62,5 \\
\hline Hayır & 18 & 37,5 \\
\hline \multicolumn{3}{|l|}{$\begin{array}{l}\text { Çocukta TYD uygulaması hakkında } \\
\text { bilgi-beceriye sahip olma durumu }\end{array}$} \\
\hline Evet & 5 & 10,4 \\
\hline Hayır & 20 & 41,7 \\
\hline Kismen & 23 & 47,9 \\
\hline \multicolumn{3}{|l|}{$\begin{array}{l}\text { Cevabı evet veya kısmen ise bu bilgi- } \\
\text { beceriyi nereden edindiği }(n=27) *\end{array}$} \\
\hline Okulda örgün eğitimde & 11 & 17,7 \\
\hline Hizmet içi eğitim & 13 & 21 \\
\hline Seminer/ Kursa & 15 & 24,2 \\
\hline Televizyon ve/veya internetten & 23 & 37,1 \\
\hline \multicolumn{3}{|l|}{$\begin{array}{l}\text { Çocukta soluk yoluna YC kaçması } \\
\text { durumunda yapılması gereken } \\
\text { ilkyardım uygulamaları hakkında } \\
\text { bilgi-beceriye sahip olma durumu }\end{array}$} \\
\hline Evet & 16 & 33,3 \\
\hline Hayır & 3 & 6,3 \\
\hline Kismen & 29 & 60,4 \\
\hline \multicolumn{3}{|l|}{$\begin{array}{l}\text { Cevabı evet veya kısmen ise bu bilgi } \\
\text { beceriyi nereden edindiği }(n=45) \text { * }\end{array}$} \\
\hline Okulda örgün eğitimde & 9 & 15 \\
\hline Hizmet içi eğitim & 15 & 25 \\
\hline Seminer/ Kursa & 15 & 25 \\
\hline Televizyon ve/veya internetten & 21 & 35 \\
\hline \multicolumn{3}{|l|}{$\begin{array}{l}\text { Meslek hayatında soluk yoluna YC } \\
\text { kaçması durumuyla karşılaşma } \\
\text { durumu }\end{array}$} \\
\hline Evet & 7 & 14,5 \\
\hline Hayır & 41 & 85,4 \\
\hline \multicolumn{3}{|l|}{$\begin{array}{l}\text { Cevabı evet ise bu durumda ne } \\
\text { yaptığı }(n=7)\end{array}$} \\
\hline Diyaframa basınç uyguladım. & 1 & 14,2 \\
\hline $\begin{array}{l}\text { Diyaframa basınç uyguladım, sırtına } \\
\text { vurdum. }\end{array}$ & 1 & 14,2 \\
\hline El içi ile sırtına vurdum. & 2 & 28,5 \\
\hline $\begin{array}{l}\text { Ters çevirip midesi üzerine yumruk } \\
\text { yapıp sırtına vurdum }\end{array}$ & 1 & 14,2 \\
\hline $\begin{array}{l}\text { Ağzını kontrol edip sırtına avuç içiyle } \\
\text { yukarı doğru ittirerek vurdum. }\end{array}$ & 1 & 14,2 \\
\hline $\begin{array}{l}\text { Dizime yatırıp sırtına vurdum, çene } \\
\text { altına baskı yaptım. }\end{array}$ & 1 & 14,2 \\
\hline \multicolumn{3}{|l|}{$\begin{array}{l}\text { Çocukta TYD ve soluk yoluna YC } \\
\text { kaçması durumunda yapılması } \\
\text { gerekenler hakkında eğitim isteme } \\
\text { durumu }\end{array}$} \\
\hline Evet & 41 & 85,4 \\
\hline Hayır & 7 & 14,6 \\
\hline Toplam & 48 & 100 \\
\hline
\end{tabular}

Tablo 2 incelendiğinde öğretmenlerinin \%62,5'inin mesleki hayatı boyunca ilk yardım uygulaması gerektirecek bir durumla karşılaştığ1, \%47,9'unun çocukta temel yaşam desteği uygulaması hakkındaki bilgibeceriye sahip olma durumunu "k1smen" olarak, \%41,7'sinin ise "hayır" olarak yanıtladığ1, \%60,4'ünün ise havayoluna yabanc1 cisim kaçması durumunda yapılması gereken ilkyardım uygulamaları hakkında bilgi-beceriye sahip olma durumunu "kısmen" şeklinde ifade ettiği belirlenmiştir. Çalışma bulgularımız öğretmenlerin karşılaşabilecekleri herhangi bir ilkyardım gerektirecek duruma karşı bilgi ve becerilerinin mutlaka geliştirilmesi gerekliliğini düşündürmektedir. Çalışma bulgularımıza paralel olarak ülkemizde Isparta il merkezinde görev yapan öğretmenlerle yapılan bir çalışmada katılımcıların \%45'inin daha önce ilk yardım uygulamak zorunda kaldıklarını belirttikleri; Etiyopya'da yürütülen bir araştırmada ise öğretmenlerin \%80'inin ilk yardıma gereksinimi olan bir öğrenciyle karşılaştı

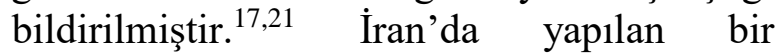
çalışmada ise öğretmenlerin yalnızca $\% 8$ 'inin ilk yardım bilgisini iyi olarak değerlendirdiği bulunmuştur. $^{22}$

Çalışmamızda öğretmenlerin \%37,1'inin "çocukta TYD"; \%35'inin ise "çocukta havayoluna yabancı cisim kaçması durumunda" yapılacak ilk yardım uygulamaları konusunda bilgi ve becerilerini "televizyon ve/veya internetten" edindiklerini belirttiği saptanmıştır. Literatürde yer alan çalışmalarda da öğretmenlerin ilk yardımla ilgili bilgi kaynaklarının çoğunlukla internet ve televizyon gibi araçlar olduğu belirtilmektedir. ${ }^{22-24}$ Özellikle internet ortamında yoğunlukla yer alan güvenilir ve güncel olmayan bilgilerin öğretmenleri ilk yardım uygulamaları konusunda yanlış yönlendirebileceği bu nedenle öğretmenlere ilk yardımla ilgili eğitimlerin sağlık profesyonelleri tarafından güncel literatüre uygun şekilde uygulamalı eğitimlerle verilmesi gerektiği düşünülmektedir.

Çalışmamızda öğretmenlerin \%14,5'i meslek hayatı boyunca öğrencisinin soluk yoluna yabancı cisim kaçması durumuyla karşılaştığını, karşılaşanların bu durumda ne 
yaptı̆̆1 sorusuna ise "Diyaframa basınç uyguladım", "Diyaframa basınç uyguladım, sırtına vurdum", "El içi ile sırtına vurdum", "Ters çevirip midesi üzerine yumruk yapıp sırtına vurdum", “A ğzını kontrol edip sırtına avuç içiyle yukarı doğru ittirerek vurdum" ve "Dizime yatırıp sırtına vurdum, çene altına baskı yaptım" şeklinde farklı ve doğru ilk yardım yaklaşımını tanımlamayan yanıtlar verdiği saptanmıştır. Bununla birlikte katılımcıların \%85,4'ünün "Çocukta temel yaşam desteği ve soluk yoluna yabancı cisim kaçması durumunda yapılması gerekenler hakkında bir eğitim almak ister misiniz?" sorusuna "evet" cevabını verdiği belirlenmiştir. Çalışma bulgularımız öğretmenlerin havayolu tıkanıklığına yaklaşım konusunda yetersiz olduğunu ve öğretmenlerin büyük bir çoğunluğunun bu konuda eğitim almaya istekli olduğunu göstermektedir. Çalışma bulgularımıza benzer şekilde ülkemizde ve farklı ülkelerde yapılan çalışmalarda da öğretmenlerin kendilerini ilk yardım konusunda yetersiz gördükleri bu nedenle eğitim almak istedikleri bildirilmektedir. ${ }^{17,21,22,24-26}$

Bu çalışmada katılımcıların ön ve son testten aldıkları puanların yaş grubuna ve meslekte çalışma y1lına göre farklılık göstermediği saptanmıştır $(\mathrm{p}>0,05)$ (Tablo 3). Çalışma sonuçlarımıza benzer şekilde Filistin ve Irak'ta öğretmenlerin ilk yardım bilgilerini değerlendirmek için yapılan çalışmalarda ilk yardım bilgisi ile yaş ve mesleki deneyim arasında anlamlı bir fark olmadığı belirlenmiştir. ${ }^{16,24}$ Sönmez ve arkadaşları (2014) tarafından yapılan çalışmada da okul öncesi öğretmenlerinin yaş ve çalışma süresi ile ilk yardım bilgisi puanları arasında anlamlı farklılık olmadığ bildirilmiştir. $^{18}$

Al-Tameemi ve Khudair tarafından yapılan çalışmada da öğretmenlerin ilk yardım bilgisi ile cinsiyet ve medeni durum arasında fark olmadığı belirlenmiştir. ${ }^{24}$ Benzer şekilde İran'da 200 öğretmenle yapılan çalışmada cinsiyet ile ilk yardım bilgi puanları arasında fark olmadığı bulunmuştur. $^{22}$ Bizim çalışmamızda da literatürle uyumlu olarak katılımcıların havayolu tıkanıklığına ilk yardım yaklaşımı bilgi düzeyi formundan aldıkları ön ve son test puanlarının cinsiyet ve medeni duruma göre farklılık göstermediği belirlenmiştir ( $>0,05)$. Çalışma bulgumuzdan farklı olarak Suudi Arabistan'da yapılan bir çalışmada ise kadın katılımcıların erkeklere göre ilk yardım bilgilerinin anlamlı düzeyde yüksek olduğu saptanmıştır. ${ }^{27}$

Tablo 3. Katılımcların Sosyodemografik Özelliklerine Göre Havayolu Tıkanıklı̆ğı İlk Yardım Yaklaşımı Bilgi Düzeyi Formundan Aldıkları Ön Test ve Son Test Puanlarmın Karşılaştırılması $(n=48)$

\begin{tabular}{|c|c|c|}
\hline Özellikler & $\begin{array}{c}\text { Ön test } \\
\text { toplam } \\
\text { puanı }\end{array}$ & $\begin{array}{c}\begin{array}{c}\text { Son test } \\
\text { toplam } \\
\text { puanı }\end{array} \\
\text { Ort. } \pm \text { SS } \\
\end{array}$ \\
\hline \multicolumn{3}{|l|}{ Yaş grubu } \\
\hline $25-34$ & $1,68 \pm 1,30$ & $6,87 \pm 2,39$ \\
\hline $35-44$ & $2,06 \pm 1,59$ & $7,30 \pm 1,66$ \\
\hline 45 ve üzeri & $1,50 \pm 0,70$ & $6,50 \pm 3,53$ \\
\hline Test İstatistiği Değeri & $\begin{aligned} \chi^{2} & =0,321 \\
p & =0,852\end{aligned}$ & $\begin{array}{r}\chi^{2}=0,077 \\
p=0,962\end{array}$ \\
\hline \multicolumn{3}{|l|}{ Cinsiyet } \\
\hline Kadın & $1,86 \pm 1,46$ & $7,06 \pm 1,98$ \\
\hline Erkek & $3,0 \pm 1,41$ & $8,50 \pm 0,70$ \\
\hline Test İstatistiği Değeri & $\begin{array}{r}\mathrm{U}=22,500 \\
\mathrm{p}=0,212\end{array}$ & $\begin{array}{r}\mathrm{U}=24,500 \\
\mathrm{p}=0,260\end{array}$ \\
\hline \multicolumn{3}{|l|}{ Medeni durumu } \\
\hline Evli & $1,88 \pm 1,49$ & $7,06 \pm 1,97$ \\
\hline Bekar & $2,33 \pm 1,15$ & $8,00 \pm 2,00$ \\
\hline Test İstatistiği Değeri & $\begin{array}{r}\mathrm{U}=48,50 \\
\mathrm{p}=0,405\end{array}$ & $\begin{array}{r}U=51,50 \\
p=0,489\end{array}$ \\
\hline \multicolumn{3}{|l|}{ Meslekte çalıșma süresi } \\
\hline $1-5$ y1l & $1,0 \pm 1,73$ & $5,33 \pm 2,08$ \\
\hline $6-10$ y1l & $2,09 \pm 1,44$ & $7,54 \pm 1,96$ \\
\hline 11 yıl ve üzeri & $1,94 \pm 1,47$ & $7,14 \pm 1,92$ \\
\hline Test İstatistiği Değeri & $\begin{aligned} \chi^{2} & =1,486 \\
p & =0,476\end{aligned}$ & $\begin{aligned} \chi^{2} & =3,315 \\
p & =0,191\end{aligned}$ \\
\hline
\end{tabular}

$\mathrm{Bu}$ çalışmada katılımcıların ön ve son testten aldıkları puanların meslek hayatında ilkyardım uygulaması gerektirecek bir durumla karşılaşma durumu, meslek hayatında öğrencilerinin soluk yoluna yabancı cisim kaçması durumuyla karşılaşma durumu, çocukta temel yaşam desteği ve soluk yoluna yabancı cisim kaçması durumunda yapılması gerekenler hakkında eğitim isteme durumu gibi değişkenlere göre farklılık göstermediği saptanmıştır $(p>0,05)$ (Tablo 4). 
Tablo 4. Katılımcıların İlkyardım ve Havayolu Tıkanıklığına Yönelik Tanımlayıcı Özelliklerine Göre Ön Test ve Son Test Puanlarının Karşılaştırılması $(n=48)$

\begin{tabular}{ccc}
\hline Özellikler & $\begin{array}{c}\text { Ön test } \\
\text { toplam } \\
\text { puanı }\end{array}$ & $\begin{array}{c}\text { Son test } \\
\text { toplam } \\
\text { puanı }\end{array}$ \\
\cline { 2 - 3 } & Ort. \pm SS & Ort. \pm SS \\
\hline
\end{tabular}

\begin{tabular}{lrr}
\hline $\begin{array}{l}\text { Meslek hayatında } \\
\text { ilkyardım uygulaması } \\
\text { gerektirecek bir } \\
\text { durumla karşılaşma }\end{array}$ & & \\
durumu & & \\
Evet & $1,86 \pm 1,52$ & $6,96 \pm 2,09$ \\
Hayır & $2,0 \pm 1,41$ & $7,38 \pm 1,75$ \\
\hline Test İstatistiği Değeri & $\mathrm{U}=247,50$ & $\mathrm{t}=-0,717$ \\
& $\mathrm{p}=0,622$ & $\mathrm{p}=0,477$ \\
\hline
\end{tabular}

Çocukta TYD

uygulaması hakkında

bilgi-beceriye sahip

olma durumu

\begin{tabular}{lrr} 
Evet $^{\mathrm{a}}$ & $3,40 \pm 1,67$ & $7,80 \pm 1,92$ \\
Hayır $^{\mathrm{b}}$ & $1,20 \pm 0,95$ & $7,0 \pm 2,10$ \\
Kısmen $^{\text {ab }}$ & $2,21 \pm 1,50$ & $7,08 \pm 1,90$ \\
\hline Test İstatistiği Değeri & $\chi^{2}=10,48$ & $\chi^{2}=0,69$ \\
& $\mathbf{p}=\mathbf{0 , 0 0 5}$ & $\mathrm{p}=0,708$ \\
\hline
\end{tabular}

Çocukta soluk yoluna

YC kaçması

durumunda ilkyardım

uygulamaları hakkında

bilgi ve beceriye sahip

olma durumu

Hayir $^{b}$

$2,62 \pm 1,62$

$7,0 \pm 1,89$

Kismen ${ }^{a b}$

$0,33 \pm 0,57$

$6,0 \pm 2,64$

Kismen ${ }^{\text {ab }}$

$1,68 \pm 1,25$

$7,31 \pm 1,96$

Öğrencilerinin soluk

$\begin{array}{rl}\chi^{2}=9,135 & \chi^{2}=1,203 \\ \mathbf{p}=\mathbf{0 , 0 1} & \mathrm{p}=0,548\end{array}$

yoluna YC kaçması

durumuyla karşılaşma

durumu

\begin{tabular}{lrr} 
Evet & $1,75 \pm 1,50$ & $6,75 \pm 2,21$ \\
Hayır & $1,93 \pm 1,48$ & $7,15 \pm 1,96$ \\
\hline Test İstatistiği Değeri & $\mathrm{U}=77,50$ & $\mathrm{U}=78,50$ \\
& $\mathrm{p}=0,687$ & $\mathrm{p}=0,719$ \\
\hline
\end{tabular}

TYD ve soluk yoluna

YC kaçması hakkında

eğitim isteme durumu

\begin{tabular}{lrr} 
Evet & $1,95 \pm 1,51$ & $7,17 \pm 1,98$ \\
Hayır & $1,71 \pm 1,25$ & $6,85 \pm 1,95$ \\
\hline Test İstatistiği Değeri & $\mathrm{U}=143,50$ & $\mathrm{U}=127,50$ \\
& $\mathrm{p}=1,000$ & $\mathrm{p}=0,635$
\end{tabular}

TYD: Temel yaşam desteği; YC: Yabancı cisim; Ort: Aritmetik ortalama; SS: Standart sapma; U: Mann Whitney U testi; $\chi^{2}$ : Kruskall-Wallis testi; t: Bağımsız Örneklem T testi; a-b: Aynı harfe sahip gruplar arasinda fark yoktur.

Bununla birlikte çocukta temel yaşam desteği uygulaması hakkında bilgi-beceriye sahip olanların olmayanlara göre; çocukta soluk yoluna yabancı cisim kaçması durumunda yapılması gereken ilk yardım uygulamaları hakkında bilgi ve beceriye sahip olanların ise olmayanlara göre ön test puanlarının daha yüksek olduğu ve aradaki farkın istatistiksel olarak anlamlı olduğu belirlenmiştir $\quad(p<0,05) \quad($ Tablo 4). Bulgularımız öğretmenlerin daha önce almış oldukları eğitimlerinin etkili olduğunu, hizmet içi eğitimler aracılığıyla bu bilgilerin sik sı pekiştirilmesi gerektiğini düşündürmektedir.

Tablo 5. Katılımcıların Havayolu Tıkanıkı̆ğına İlk Yardım Yaklaşımı Bilgi Düzeyi Formundan Aldıkları Ön Test ve Son Test Puanları

\begin{tabular}{|c|c|}
\hline Test Türü & Ort. \pm SS \\
\hline Ön test puanı & $1,91 \pm 1,47$ \\
\hline Son test puanı & $7,12 \pm 1,96$ \\
\hline Test İstatistiği Değeri & $\mathrm{p}=0,000, \quad \mathrm{Z}=-5,986$ \\
\hline
\end{tabular}

$\mathrm{Bu}$ çalışmada öğretmenlerin havayolu tıkanıklığına ilk yardım yaklaşımı bilgi düzeyi formundan aldıkları ön test puan ortalamasinın $1,91 \pm 1,47$; son test puan ortalamasının ise $7,12 \pm 1,96$ olduğu saptanmıştır (Tablo 5). Ön test ve son test puan ortalamaları arasındaki farkın ileri düzeyde anlamlı olduğu belirlenmiştir ( $p$ $<0,001, Z=-5,986)$. Çalışma bulgularımıza benzer şekilde öğretmenlerin ilk yardım ve TYD bilgisini değerlendirmek için yapılan deneysel bir çalışmada katılımcıların eğitim öncesi ön test puanları ile eğitim sonrası son test puanları arasında anlamlı düzeyde fark olduğu bildirilmiştir. ${ }^{28}$ Ülkemizde Arli ve arkadaşları (2017) tarafindan yapılan ön testson test kontrol gruplu deneysel bir çalışmada deney grubunda yer alan ögretmenlere ilk yardım hakkında teorik ve uygulamalı eğitim verilmiş, eğitim sonrası puanların eğitim öncesine göre anlaml düzeyde arttı̆̆1 belirlenmiştir. ${ }^{29}$ Benzer şekilde Misır'da ve Hindistan'da yapılan çalışmalarda da öğretmenlerin eğitim sonrası ilk yardım bilgisi puanlarının eğitim öncesi puanlara göre anlamlı düzeyde yüksek olduğu bulunmuştur. ${ }^{25,30}$ Çalışma bulgumuz anaokulu öğretmenlerine ilk yardım konusunda verilen eğitimin etkili olduğunu ve ilk yardım eğitimlerinin düzenli aralıklarla öğretmenlere verilmesi gerektiğini düşündürmektedir. 


\section{SONUÇ VE ÖNERILER}

Anaokulu çocuklarının karşılaştığı herhangi bir acil durumda öğretmenlerin hızlı, doğru ve bilinçli ilk yardım uygulamalarını yapabilmeleri çocuğun hayatının kurtarılmasını sağlama, durumunun kötüleşmesi ve sakat kalmasını önleyebilmek adına oldukça önemli bir konudur. Özellikle yaş dönemi itibariyle yabanc1 cisim aspirasyonları yönünden risk grubunda bulunan bu çocuklara acil bir durumda yapılması gereken ilk yardım uygulamalarının başta ebeveynler ve öğretmenler olmak üzere tüm bakıcıları tarafindan bilinmesi gerekir. $\mathrm{Bu}$ çalışmada anaokulu öğretmenlerine verilen çocukta havayolu tıkanıklığında ilkyardım yaklaşımı eğitiminin, katılımcıların bilgi düzeyini arttırmada etkili olduğu belirlenmiștir. Bulgularımız doğrultusunda; anaokulu öğretmenlerine düzenli aralıklarla çocukta havayolu tıkanıklığı konusunda yüz yüze uygulamalı eğitimler verilmesi, ilk yardım eğitimlerinin tüm illerin milli eğitim müdürlükleri tarafından zorunlu hizmet içi eğitim kapsamına dahil edilmesi, anaokullarının sınıf, koridor vb. alanlarına çocukta temel yaşam desteği, havayolu tıkanıklığına yaklaşım gibi acil durumlara yönelik ilk yardım yaklaşımlarının görünür şekilde asılması ve okul öncesi öğretmenliği lisans müfredatında ilk yardım konulara daha fazla yer verilmesi önerilmektedir.

\section{KAYNAKLAR}

1. Kurtulus, A, Demir, S, Sarıtas, M.S, Boz, B. ve Acar, K. (2012). "Çocukta Yabancı Cisim Aspirasyonu Sonucu Ölüm”. Pamukkale Tıp Dergisi, 5 (2), 87-90.

2. Cramer, N, Jabbour, N, Tavarez, M.M. and Taylor, R.S (2020). "Foreign Body Aspiration". Treasure Island (FL) StatPearls Publishing. Erișim adresi: https://www.ncbi.nlm.nih.gov/books/NBK531480/ (Erişim tarihi: 3 Mart 2021)

3. Fraga, A.M, Reis, M.C, Zambon, M.P, Toro, I.C, Ribeiro, J.D. and Baracat, E.C. (2008). "Foreign Body Aspiration in Children: Clinical Aspects, Radiological Aspects and Bronchoscopic Treatment". Jornal Brasileiro de Pneumologia, 34 (2), 74-82.

4. Brkic, F. Umihanic, S, Altumbabic, H, Ramas, A, Almir, S, Umihanic, S. and Zulcic, S. (2018). "Death as a Consequence of Foreign Body Aspiration in Children". Med Arch, 72 (3), 220-23

5. Salih, A.M, Alfaki, M. and Alam-Elhuda, D.M. (2016) "Airway Foreign Bodies: A Critical Review for a Common Pediatric Emergency". World Journal of Emergency Medicine, 7 (1), 5-12.

6. Sidell, D. R, Kim, I. A, Coker, T. R, Moreno, C. and Shapiro, N. L. (2013). "Food Choking Hazards in Children". International Journal of Pediatric Otorhinolaryngology, 77 (12), 1940-1946.

7. Tatsanakanjanakorn, W. and Suetrong, S. (2016). "Do Times until Treatment for Foreign Body Aspiration Relate to Complications". International Journal of Otolaryngology, e2831614. (published online)

8. Tekant, G.T. ve Özcan, R. (2015). "Yabanc1 Cisim Aspirasyonları". Turkiye Klinikleri Pediatric SurgerySpecial Topics, 5 (2),72-78.

9. Lowe, D.A, Vasquez, R. and Maniaci, V. (2015). "Foreign Body Aspiration in Children". Clinical Pediatric Emergency Medicine, 16 (3), 140-1448.

10. Cobanoğlu, U. ve Can, M. (2008). "0-7 Yas Dönemi Çocuklarda Özofagus Yabancı Cisimleri”. Van Tıp Dergisi, 15 (2), 51-57.

11. Boufersaoui, A, Smati, L, Benhalla, K. N, Boukari, R, Smail, S, Anik, K, Aouameur, R, Chaouche, H. and Baghriche, M. (2013). "Foreign Body Aspiration in Children: Experience from 2624 Patients". International Journal of Pediatric Otorhinolaryngology, 77 (10), 16831688 .
12. Millî Eğitim Bakanlığg Okul Öncesi Eğitim ve İlköğretim Kurumları Yönetmeliğinde Değişiklik Yapılmasına Dair Yönetmelik (2019). Resmî Gazete Sayı: 30827 , 10/07/2019.

13. Amerikan Pediatri Akademisi. (2017). "First Aid Guide for Parents \& Caregiver". Erișim adresi: https://www.healthychildren.org/English/safetyprevention/at-home/Pages/First-Aid-Guide.aspx (Erisim tarihi: 5 Ocak 2021)

14. Onganlar, Y.H, Şahin, M, Pak, F.O. ve Şahin, H.H.K (2019). "Pediatride Temel Yaşam Desteği". Sağlık Bilimleri ve Tip Dergisi, 2 (4), 139-45

15. Kim, I.A, Shapiro, N. and Bhattacharyya, N. (2015). "The National Cost Burden of Bronchial Foreign Body Aspiration in Children". The Laryngoscope, 125 (5), 122124

16. Amro, N. R. and Qtait, M. (2017). “General Knowledge \& Attitude of First Aid Among School Teacher's in Palestine". International Journal of Innovative Research in Medical Science, 2 (4), 660-65

17. Nayir, T. Uskun, E, Türkoğlu, H, Uzun, E, Öztürk, M. ve Kişioğlu A.N. (2011). "Isparta İl Merkezinde Görevli Öğretmenlerin İlk Yardım Bilgi Düzeyleri ve Tutumları". SDÜ Tıp Fakültesi Dergisi, 18 (4), 123-27.

18. Sönmez, Y, Uskun, E. ve Pehlivan, A. (2014). "Okul Öncesi Öğretmenlerinin İlk Yardım Bilgileri”. Türk Pediatri Arşivi, 49, 238-246.

19. Dinçer, C, Atakurt, Y. ve Şimșek, I. (2000). "Okul Öncesi Eğitimcilerinin İlk Yardım Bilgi Düzeyleri Üzerine Bir Araştırma". Ankara Üniversitesi Tıp Fakültesi Mecmuası, 53 (1), 31-38.

20. The Global First Aid Reference Centre (2020). "First Aid Guidelines". Erişim adresi: https://www.globalfirstaidcentre.org/ (Erişim tarihi: 24 Mayıs 2021).

21. Ganfure, G, Ameya, G, Tamirat, A, Lencha, B. and Bikila, D. (2018). "First Aid Knowledge, Attitude, Practice, and Associated Factors Among Kindergarten Teachers of Lideta Sub-city Addis Ababa, Ethiopia”. Plos One, 13 (3), e0194263.

22. Adib-Hajbaghery, M. and Kamrava, Z. (2019). "Iranian Teachers' Knowledge About First Aid in the School Environment". Chinese Journal of Traumatology, 22 (4), 240-245. 
23. Gowri, M. and Missiriya, S. (2017). "Knowledge and Practice of School Teachers on Health Care of School Children". International Journal of Pharma and Bio Sciences, 8 (1), 227-31.

24. Al-Tameemi, H.M.A. and Khudair, F.W. (2016). "Knowledge and Attitudes of Primary School Teachers Toward First Aid in Al-Najaf Al-Ashraf City". International Journal of Current Research and Academic Review, 4 (12), 64-79.

25. Hosapatna, M, Bhat, N, Prakash, J, Sumalatha, S. and Ankolekar, V.H. (2020). "Knowledge and Training of Primary School Teachers in First Aid-A Questionnaire Based Study". The Kurume Medical Journal, 10.2739/kurumemedj.MS662001 (published online).

26. Qureshi, F.M, Khalid, N, Nigah-E-Mumtaz, S, Assad, T. and Noreen, K. (2018). "First Aid Facilities in the School Settings: Are Schools able to Manage Adequately?". Pakistan Journal of Medical Sciences, 34 (2), 272-76.
27. Al Gharsan, M. and Alarfaj, I. (2019). "Knowledge and Practice of Secondary School Teachers about First Aid". Journal of Family Medicine and Primary Care, 8 (5), 1587 1593.

28. Behairy, A.S. and Al-Batanony, M.A. (2016). "Effectiveness of First Aid and Basic Life Support Intervention Program on School Health Advisors". Journal of Health Medicine and Nursing, 24, 136-144.

29. Arli, S.K. and Yildirim, Z. (2017). "The Effects of Basic First Aid Education on Teachers' Knowledge Level: A Pilot Study". International Journal of Caring Sciences, 10 (2), 813-18.

30. Abo Elsoud, M.A, Ahmed, H.A, Ahmed, A.M.A. and Frag, H.K. (2018). "Assessment Knowledge of Primary Schools Teachers about First Aid at Ismailia City". IOSR Journal of Nursing and Health Science, 7, 79-85. 